\title{
Results of surgical treatment of ventricular septal defect
}

\author{
W. Bircks and Chr. Reidemeister \\ From the Surgical Clinic of the University of Düsseldorf, Department B, \\ 4 Düsseldorf, W. Germany
}

Surgical technique in the treatment of isolated ventricular septal defect is widely standardized at the present time. One-stage and two-stage operations are not in competition with each other, but complete the surgical treatment in different indications for operation.

\section{Indications for operation and surgical technique}

The indication for operations for ventricular septal defects is directly related to the sequelae of left-to-right shunt and the danger of the development of pulmonary vascular disease. In addition there is a higher incidence of bacterial endocarditis in patients even with small left-to-right shunts (Plauth et al., 1965). The raised pulmonary blood flow may already necessitate an operative palliation in the first year of life, while the time of choice for corrective surgery is between the fourth and sixth year (Bircks, 1969).

Large ventricular septal defects in babies often lead to cardiac failure, and during infancy to the danger of fixed pulmonary vascular resistance. In babies the use of extracorporeal circulation, which is necessary for the closure of the defect, still includes a high risk. In these cases a banding procedure according to the principles of Dammann and Muller is indicated. Haemodynamic measurements during operation (Bircks et al., 1965) and postoperative observations have shown that a 50 per cent reduction of the systolic pulmonary pressure distal to the tape in comparison with intraventricular pressures leads to good results (Bircks and Loogen, 1968). Banding with a $4 \mathrm{~mm}$. Teflon tape (Fig. I) around the main pulmonary artery is done under simultaneous registration of the pulmonary and ventricular pressures. The final degree of the artificial pulmonary stenosis is fixed by suturing the tape (Goldblatt et al., 1965).

An angiocardiogram after a banding procedure shows the necessity of an anatomically high degree of stenosis (Fig. 2). This palliation must be followed by an early definitive repair. Usually, after a time interval of two to four years the pulmonary vascular resistance decreases sufficiently. The corrective operation includes the closure of the ventricular septal defect and the release of the band. In some cases a patch-plasty of the artificial pulmonary stenosis is necessary (Bircks and Loogen, I968; Dobell et al., I968).

In the different types of ventricular septal defect (types I-IV, Fig. 3) the group comprising the largest number of defects is that of the high ventricular septal defect located just under the crista supraventricularis (Kirklin and DuShane, 1963). The closure of a small ventricular septal defect located in the membranous portion of the ventricular septum near the anteromedial commissure of the tricuspid valve may be done by direct suture through a right atrial approach (Fig. 4). Large septal defects normally may be exposed by a ventricular incision. The opening of the right ventricle is done by a transverse incision at the lower portion of the right outflow tract (Fig. 5). For the closure of the defect a patch is necessary (Dubost et al., I964; Hallman et al., 1964; Kirklin and DuShane, 1963; Lillehei et al., 1964). The patch is fixed by single stitches or running sutures, avoiding the bundle of His at the lower border of the defect (Fig. 6). The patch is quickly incorporated by scar tissue with a neointimal layer.

\section{Early results of surgical treatment}

Papers on the results of surgical treatment of ventricular septal defect give an incomplete survey at present. Those published by surgical teams show the hospital mortality and complications. Large series of long-term results are rare, especially observations of the postoperative development of pulmonary vascular disease. In addition, final results are, of 


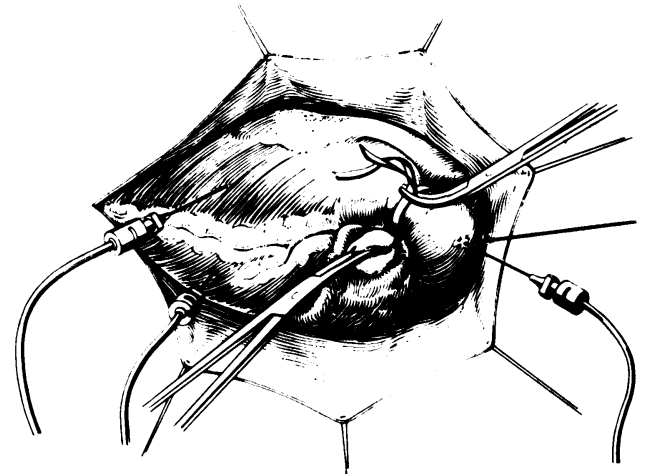

FIG. I Banding procedure. Left-sided thoracotomy, longitudinal incision of the pericardium, $4 \mathrm{~mm}$. Teflon tape around the pulmonary artery trunk, pressure-recordings by needlepuncture of both the ventricles and the pulmonary artery.

course, not available at prese ntbecause experience with larger series of patients covers only a maximum of 12 years.

The hospital mortality of primary closure of septal defects increases with the degree of pulmonary vascular disease. A summary of the overall hospital mortality rate is affected by

FIG. 2 Banding procedure. A postoperative angiocardiogram showing the high degree of pulmonary artery narrowing.

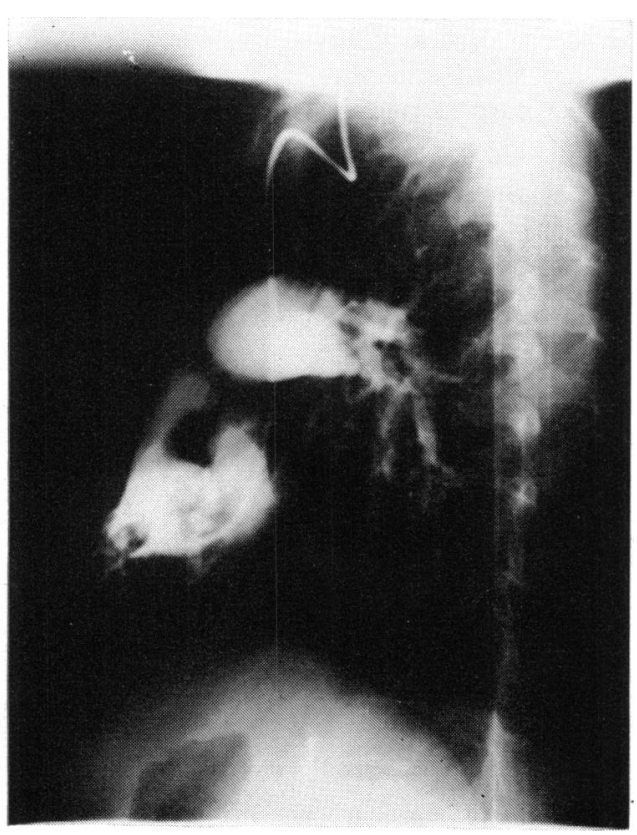

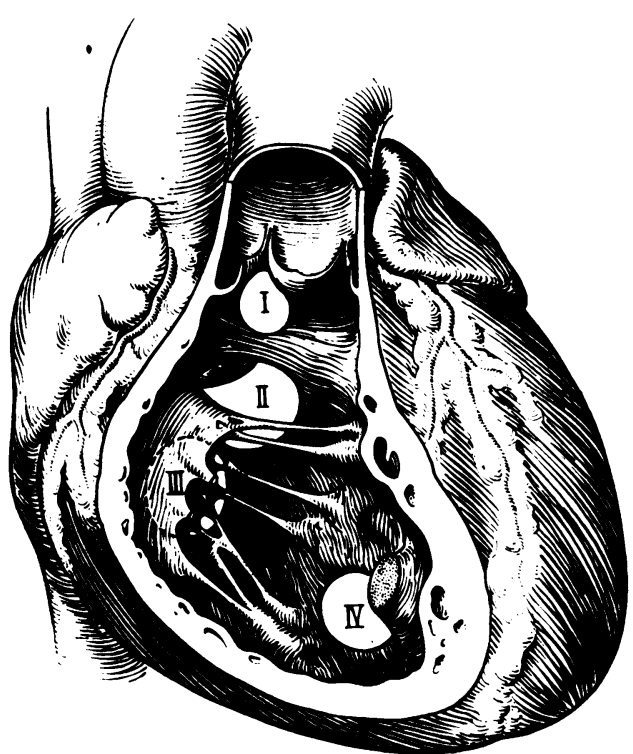

FIG. 3 Types of ventricular septal defects (according to the classification of Kirklin and DuShane, 1963).

the accidental composition of the series and does not show a true result (Table I). A classification of the patients in three groups with normal, moderately raised, and extremely high pulmonary vascular resistance (Table 2) gives more precise results.

These figures of our patients treated surgically are from an unselected series comprising all operations since 1959. The hospital mortality decreased in the later years. According to published reports the hospital mortality rate of surgical repair of small ventricular septal defects with normal pulmonary vascular resistance should be under I per cent and of large defects under ro per cent at present.

FIG. 4 Repair of ventricular septal defect. Transatrial approach for closure of small defects; direct suture.

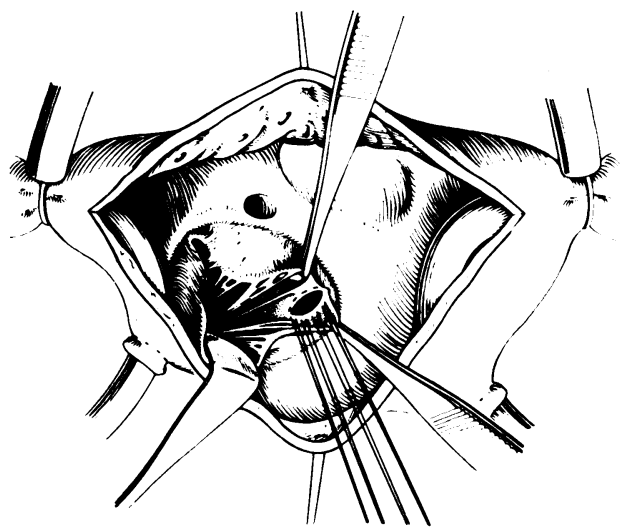


TABLE I Isolated congenital lesions with left-to-right shunt. Operative mortality including all hospital deaths. (Düsseldorf, 1949 to April 1970)

\begin{tabular}{|c|c|c|}
\hline Lesion & $\begin{array}{l}\text { Number } \\
\text { of cases }\end{array}$ & $\begin{array}{l}\text { Operative } \\
\text { mortality } \\
\%\end{array}$ \\
\hline Ductus arteriosus & 1020 & $\mathbf{I} \cdot 3$ \\
\hline Atrial septal defect, secondary & 1125 & $3 \cdot I$ \\
\hline Atrial septal defect, primary & 137 & $12 \cdot \mathbf{I}$ \\
\hline Ventricular septal defect & 412 & $7 \cdot 2$ \\
\hline
\end{tabular}

TABLE 2 Ventricular septal defect (with or without patent ductus). Operative mortality (including all hospital deaths) related to pulmonary vascular resistance. (Düsseldorf, 1959 to December 1965)

\begin{tabular}{ll}
\hline $\begin{array}{l}\text { Pulmonary vascular resistance } \\
\left.\text { (dynes/sec. } / \mathrm{cm}^{-5}\right)\end{array}$ & $\begin{array}{l}\text { Operative mortality } \\
\%(n=25 I)\end{array}$ \\
\hline$<200$ & $\mathrm{r} \cdot 3$ \\
$200-800$ & $13 \cdot 3$ \\
$>800$ & $35 \cdot 7$ \\
\hline
\end{tabular}

In palliative procedures in babies and infants the operative risk increases rapidly according to the severity of associated lesions. The published results are not comparable, because the selection of the patients and medical treatment have even more influence in babies than in children. Our own results in the group of ventricular septal defects with or without patent duct or with additional transposition of the great arteries (Table 3) are favoured by the fact that they include only a small number of babies under the age of three months. The poor prognosis of babies with multiple congenital lesions is widely accepted.

There has been little experience anywhere in the world with the so-called 'debanding'

TABLE 3 Banding procedure. Operative and hospital mortality. (Düsseldorf, 1964 to March 1970)

\begin{tabular}{|c|c|c|}
\hline Diagnosis & $\begin{array}{l}\text { Banding: } \\
\text { number } \\
\text { of cases }\end{array}$ & Deaths \\
\hline \multirow[t]{2}{*}{$\begin{array}{l}\text { Ventricular septal defect } \\
\text { + patent ductus } \\
\text { Ventricular septal defect } \\
\text { + transposition of great } \\
\text { arteries }\end{array}$} & 67 & 6 \\
\hline & 80 & $8(=10 \%)$ \\
\hline $\begin{array}{l}\text { Ventricular septal defect } \\
\quad+\text { multiple other lesions }\end{array}$ & 18 & I4 $(=78 \%)$ \\
\hline
\end{tabular}

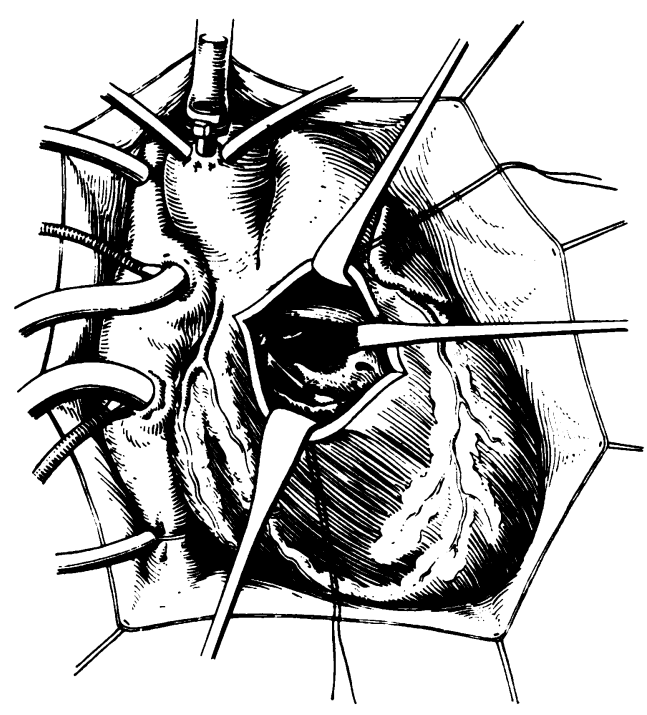

FIG. 5 Repair of ventricular septal defect. Transverse ventriculotomy for the transventricular approach to large defects.

procedure (Bircks and Loogen, 1968; Dobell et al., 1968). The hospital mortality ranges from 5 per cent to 30 per cent. In our own series of 14 operations we found two patients with a functional single ventricle and one patient with a total AV canal, which were not correctable. Among the remaining II patients we had two operative deaths, one from cardiac failure and one from pulmonary complications. The results including postoperative heart catheterization were satisfactory in nearly all cases. This series is still too small and the observation period still too short to permit final conclusions.

FIG. 6 Repair of ventricular septal defect. Closure of large defect by the aid of a patch.

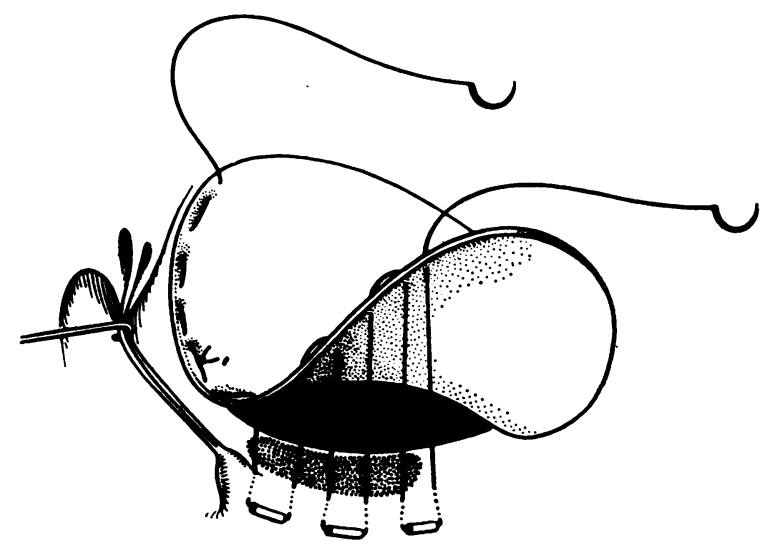




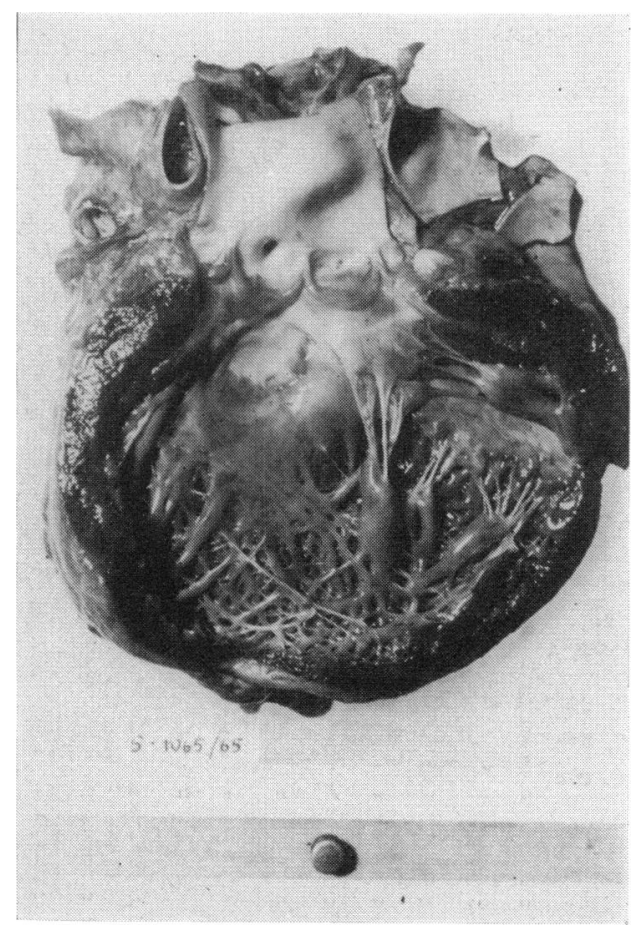

FIG. 7 Complete incorporation of a Teflon patch closing a subaortic ventricular septal defect (one year after surgery).

The main operative and postoperative complications also influence the early results of corrective and palliative surgery. Permanent total heart block by operative damage to the bundle of His can be avoided nowadays in nearly all cases. We did not experience this complication in the last hundred consecutive cases. Myocardial failure because of insufficient myocardial protection and inflammatory pulmonary complications are the main causes of postoperative mortality.

Residual defects and the reopening of defects after their repair are a real problem. The frequency of these complications is directly related to the size of the original defect. Residual or reopened defects are extremely rare with small ventricular septal defects, but in series of large defects they must still be expected in nearly Io per cent (Bircks and Satter, 1965). Not all residual shunts necessarily need an additional operation. In our experience final and safe surgical closure of these defects is possible with a low mortality rate.

\section{Late results of surgical treatment}

Long-term follow-up series with repeated cardiac catheterization of surgically corrected patients are rare. We therefore summarize the conclusions of our cardiological team (GrosseBrockhoff and Loogen, 1968) on preoperative and repeated postoperative catheterization (Fig. 8).

Our series comprised 65 patients with pulmonary hypertension. With rare exceptions the mean pulmonary artery pressure was decreased 6-8 weeks after operation. In 30 per cent of the cases the pressure was reduced to normal. In 5 patients the pressure was unchanged; in 2 patients, increased. In these 2 patients the preoperative pulmonary vascular resistance was found to be 600 and 1000 dynes $/ \mathrm{sec} . / \mathrm{cm} .,^{-5}$ respectively. During the further postoperative follow-up study (Fig. 9) a slight additional decrease of the mean pulmonary pressure was observed. In one patient the high pressure remained unchanged. In two patients the pressure increased again, exceeding the preoperative value in one case.

The number of patients being followed postoperatively is still too small and the follow-up period too short for final conclusions. For example, it is not known whether in children with postoperative persisting pulmonary hypertension the degree of the pulmonary vascular disease remains constant or whether

FIG. 8 Results of surgical treatment of ventricular septal defects with elevation of the pulmonary artery mean pressure. Changes in pulmonary artery mean pressure after closure of ventricular septal defects related to age and postoperative time interval (reproduced with permission from Grosse-Brockhoff and Loogen, 1968).

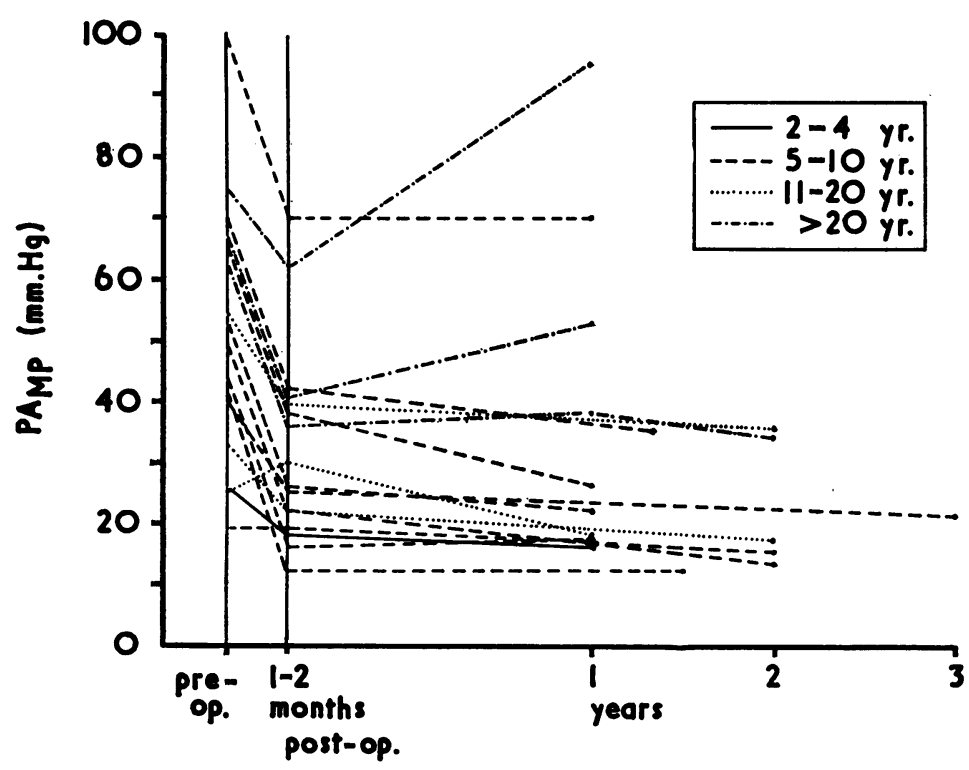




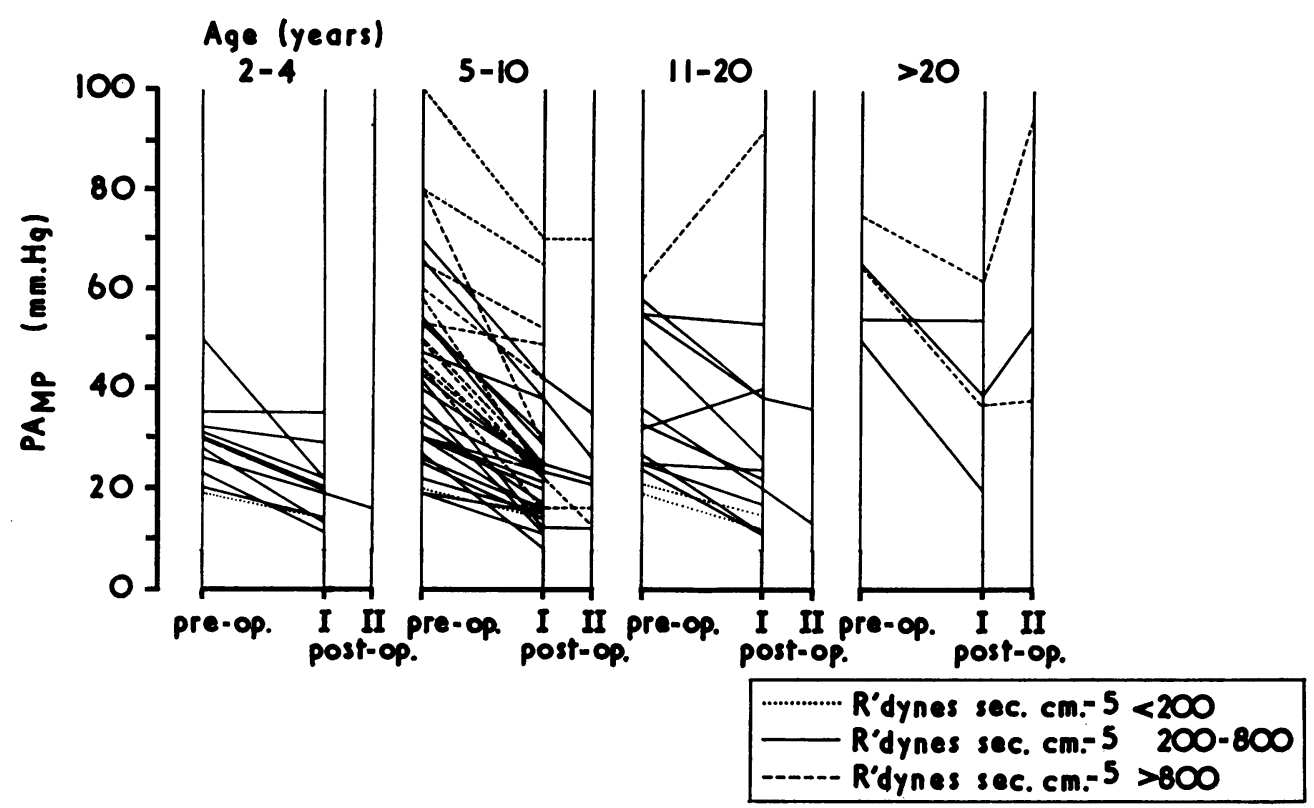

FIG. 9 Results of surgical treatment of ventricular septal defects with elevation of the pulmonary artery mean pressure. Postoperative changes of the pulmonary artery mean pressure in relation to age groups of patients and pulmonary vascular resistance (reproduced with permission from Grosse-Brockhoff and Loogen, 1968).

it increases as in patients with primary pulmonary hypertension. There are some case reports which show the possibility of such a lethal complication (Beuren, 1970; F. Loogen, personal communication). How cardiotomy and a possible right bundle-branch block will affect the future course of these patients remains to be seen.

\section{Conclusions}

Surgery has altered the natural history of ventricular septal defect in several ways. It has definitely saved many babies and infants who would otherwise have died at an early age. In other cases surgery has improved circulatory dynamics as well as the clinical picture. Probably it can be concluded that these patients are in a better physical state and that their life expectancy has been increased.

In some cases no improvement has been achieved by surgery, and some patients have deteriorated postoperatively. In those who still have pulmonary hypertension during the immediate postoperative period the pressure usually decreases later on, but in some patients the elevated pressure remains unchanged. Fortunately the pressure increases in only a few cases. It is assumed that in some cases progressive pulmonary sclerosis develops later on, but the final solution of this problem cannot be found without further observation and better documentation. From a surgical point of view the operative treatment of ventricular septal defect carries a reasonable risk for the patient.

\section{References}

Beuren, A. J. (1970). Fehlindikationen in der Kardiochirurgie des frühen Kindesalters. Langenbecks Archiv für Klinische Chirurgie, vereinigt mit Deutsche Zeitschrift für Chirurgie, 327,'667.

Bircks, W. (1969). Operative Korrektur von angeborenen Herzfehlern ohne Cyanose. Kongressbericht der Österreichische Gesellschaft für Chirurgie, I0, 114 .

-, Bostroem, B., Kreuzer, H., and Loogen, F. (1965). Die Dosierung einer künstlichen Pulmonalstenose mit Hilfe intraoperativer HerzzeitvolumenBestimmungen. Langenbecks Archiv für Klinische Chirurgie, vereinigt mit Deutsche Zeitschrift für Chirurgie, 313, 676.

$\longrightarrow$, and Loogen, F. (1968). Die Bändelungsoperation (und der nachfolgende Korrektureingriff). Langenbecks Archiv für Klinische Chirurgie, vereinigt mit Deutsche Zeitschrift für Chirurgie, 322, 641.

- and Satter, P. (1965). Zur Problematik des Rezidiv-Ventrikelseptumdefektes. Thoraxchirurgie, I3, $26 \mathrm{r}$.

Dobell, A. R. C., Murphy, D. R., Gibbons, J. E., and Dubost, C. (1968). Pulmonary artery debanding. Annals of Thoracic Surgery, 5, 435.

Dubost, C., Blondeau, P., Piwnica, A., and de Parades, B. (I964). Traitement chirurgicale des communications interventriculaires avec hypertension artérielle pulmonaire. Archives des Maladies du Coeur et des Vaisseaux, 57, 1346. 
Goldblatt, A., Bernhard, W. F., Nadas, A. S., and Gross, R. E. (1965). Pulmonary artery banding. Circulation, 32, 172.

Goldblatt, A., Weber, A., and Halldorsson, T. S. (1965). Pulmonary artery banding in infants and children. Clinical Pediatrics, 4, 659.

Grosse-Brockhoff, F., and Loogen, F. (1968). Ventricular septal defect. Circulation, 37-38, Suppl. 5 , 13.

Hallman, G. L., Cooley, D. A., Wolfe, R. R., and McNamara, D. G. (1964). Surgical treatment of ventricular septal defect associated with pulmonary hypertension. Fournal of Thoracic and Cardiovascular Surgery, 48, 588.

Kirklin, J. W., and DuShane, J. W. (1963). Indications for repair of ventricular septal defects. American fournal of Cardiology, 12, 75.

Lillehei, C. W., Levy, M. J., Adams, P., and Anderson, R. C. (1964). High-pressure ventricular septal defects. Fournal of the American Medical Association, 188, I 17.

Plauth, W. H., Jr., Braunwald, E., Rockoff, S. D., Mason, D. T., and Morrow, A. G. (1965). Ventricular septal defect and aortic regurgitation. American fournal of Medicine, 39, 552. 